\title{
IMPACT OF EMOTIONAL INTELLIGENCE ON JOB SATISFACTION AT TATA CONSULTANCY SERVICES, CHENNAI, TAMILNADU STATE A CASE STUDY
}

\author{
Sanjana Kumari Gonnabathula \\ Research scholar, Alagappa Institute of Management, Alagappa University \\ Karaikudi, Tamilnadu, India \\ Dr. S Chandramohan \\ Professor, Alagappa Institute of Management, Alagappa University \\ Karaikudi, Tamilnadu, India
}

\begin{abstract}
In the current scenario, the business environment is very relatively competitive, organizations face various challenges. The employees play a vital role in the sense of people at work hard for the organization. Most of the organizations believe that the employees are work as a team and an effective approach, it will not only solve employee motivation but also organization productivity of goals that may overcome. The employees expected to produce results but the performance will be hindered if the team members are not working well together. Hence it should know that the organizations have to know that the components of employee emotional intelligence at work. The purpose of conducting the research work is to explore the independent variables of emotional intelligence at Tata Consultancy Services. The study of the data collection forms a structured questionnaire via a convenient sampling method.
\end{abstract}

Key words: Emotional Intelligence, Dimensions of emotional intelligence, job satisfaction

Cite this Article: Sanjana Kumari Gonnabathula and S Chandramohan, Impact of Emotional Intelligence on Job Satisfaction at Tata Consultancy Services, Chennai, Tamilnadu State A Case Study, International Journal of Management, 11(12), 2020, pp 3239-3248.

http://iaeme.com/Home/issue/IJM?Volume=11\&Issue=12

\section{INTRODUCTION}

In the current business environment, it is relatively competitive for organizations to face various challenges. The employees play an important role as the behind that strive and work hard for the organization. Most organizations believe that teamwork is an effective approach to improve 
the productivity of organization goals. When the employees are in the team they are expected to produce results but the performance of the employee will be hindered by the employees not working well together. Hence employee's works in the origination as a team is the key point to increase the performance.

Emotional Intelligence: Emotional Intelligence is two phrases that are emotions and intelligence. Emotional intelligence can be defined as the ability to accurately perceive understand emotions and to use them to enhance thought. Emotional intelligence is the competence of an individual to recognize, apply, comprehend and understand emotional behavior in an optimistic manner. Emotional intelligence would be the aptitude to understand emotions and to augment the thinking process. It includes the capabilities to precisely identify emotions to generate emotions, to identify emotions, to identify emotional awareness to control emotions. Emotional intelligence consists of four dimensions that are self-awareness, selfmanagement, social awareness, and social management. The study was constructed to SelfEmotional Appraisal, Others emotional Appraisal, Use of Emotions and Regulation of Emotions.

\subsection{Job Satisfaction}

Job satisfaction has been extensively about the organizations as well as employee's immense competition due to globalization, a lot of importance is being given to job satisfaction. A multitasking approach of an individual towards the job is referred to as job satisfaction. It is an emotional state when a person gets the appraisal for his job and is to facilitate for the achievement in the job. The perception of an individual workplace towards his job is referred to as job satisfaction. A person with a high level of job satisfaction holds a positive attitude towards the job, the dissatisfaction referred to a negative attitude towards job satisfaction.

\subsection{Self-Emotional Appraisal}

The research work is providing the problem of job satisfaction by examining the relationship of job satisfaction with emotional intelligence.

- Other Emotional Appraisal

- Job Satisfaction

- Use of Emotional

- Control of Emotions

Figure 1 Emotional Intelligence and Job Satisfaction

\section{REVIEW OF LITERATURE}

Tabatabaei and Farazmehr(2015) in their study, it was found that gender has insignificantly influenced job satisfaction, emotional intelligence significantly influences job satisfaction, emotional intelligence and gender interact to influence job satisfaction.

Kurien(2013) study was conducted among 150 employees of a famous retail store in India. The service quality of a retail store would be enhanced the employees of the store practiced emotional intelligence skills.

Jorfietal(2012) was found that women have higher emotional intelligence than men.

Syed, Rohany, Mohamad, Mohamed, and Muhammad (2012) found a significant positive relationship between EI and Job satisfaction and no effect of gender on EI and job satisfaction.

Ealias and George (2012) found that there a significant difference between emotional intelligence and married and unmarried respondents. 
Khouly, Ghoneim, Ghadami, \& Ibrahim (2011) in his study he found that gender has insignificantly influenced job satisfaction, significantly emotional intelligence and job satisfaction, gender influenced job satisfaction.

Pande(2010) studied the emotional intelligence of teachers and the study shows that teachers have a higher level of emotional intelligence than unmarried ones. There is a significant difference between teacher and student on emotional intelligence.

Radhakrishanan and Udaysuriyan (2010) found that the executives have some qualities of concern for others, stress tolerance and optimal emotional intelligence.

(Radhakrishnan and UdayaSuriyan, 2010). They found that those executives have some qualities like, concern for others, stress tolerance which helped them in having optimal emotional intelligence.

Yao et.al (2009) conducted a study on emotional intelligence on job performance effects on leadership. The study explains that the managers and their employees the emotional intelligence have significant and positive correlations with job performance.

Khokharet (2009) explained the performance of executives on a different level of emotional intelligence and effective work performance. The study revealed that executives having higher emotional intelligence shows a better quality of work performance.

Hayward (2005) the research investigated the relationship between employee performance, leadership and emotional intelligence with linear regression analysis. the study shows that there is a significant relationship between employee performance and emotional intelligence, and there no significant relationship between employee performance and emotionally intelligent. The correlation shows a weak relationship between emotional intelligence and leadership.

Kerbach and Schutte (2005) Higher level of emotional intelligence of the service provider to higher customer satisfaction.

Nel H (2004) studied on emotional intelligence the study shows that there is a significant relationship between emotional intelligence and job performance in a call center environment. There is a high level of job performance in the respective call centers to be associated with the high level of emotional intelligence.

Goleman (2000) presents a set of the theoretical framework of emotional intelligence that reflects how an individual mastering the skills of Self Awareness, Self-Management, Social Awareness and Relationship Management on job success. The theory focusing on performance, workplace performance and factors that distinguish the best individuals.

\section{NEED FOR THE STUDY}

Emotional Intelligence helps the employees to increase their emotional self-awareness, emotional expression, creativity, trust and integrity, improves relations within the organization and increases the performance of each employee. Emotional intelligence is one of the few key characteristics that rise to strategic leaders in the organization. Emotional intelligence plays a vital significant role in the organization and for the judgment of effective employees, improvement of productivity and trust in the organization.

\section{OBJECTIVES OF THE STUDY}

- To study the employee's awareness of emotional intelligence in tata Consultancy Services

- To study the determinants of emotional intelligence of employees at tata Consultancy Services. 
Impact of Emotional Intelligence on Job Satisfaction at Tata Consultancy Services, Chennai,

Tamilnadu State A Case Study

- To analyze the association between of employees' emotional intelligence and job satisfaction at Tata Consultancy Services.

\section{RESEARCH METHODOLOGY}

The study is to investigate the relationship between emotional intelligence and job satisfaction among the employees in the Tata Consultancy.

The primary data was collected through the self-administered survey questionnaire to 100 respondents. The secondary data was collected from journals, books and websites. The independent variable was emotional intelligence and the dependent variable was job satisfaction. The four dimensions of emotional intelligence Self emotional appraisal, and control of emotions. The measurements for all the dimensions were inspected using 5 points Likert scale where 1=Strongly Disagree and 5= strongly Agree, where 1=Highly Dissatisfied and $5=$ Highly Satisfied. The data collected were analysed using SPSS version 23.0 by descriptive analysis, reliability test and correlation test performed.

\section{HYPOTHESIS}

- H1: There is no association between Emotional intelligence and employee job satisfaction

- H2: There is an association between Emotional intelligence and employee job satisfaction

\section{DATA ANALYSIS}

Table 1 Demographic Variables

\begin{tabular}{|c|c|c|c|c|}
\hline GENDER & Frequency & Percent & Valid Percent & Cumulative Percent \\
\hline \multirow{3}{*}{$\begin{array}{c}\text { Male } \\
\text { Female } \\
\text { Total }\end{array}$} & 74 & 74.0 & 74.0 & 74.0 \\
\hline & 26 & 26.0 & 26.0 & 100.0 \\
\hline & 100 & 100.0 & 100.0 & \\
\hline $\mathrm{AGE}$ & Frequency & Percent & Valid Percent & Cumulative Percent \\
\hline \multirow{5}{*}{$\begin{array}{c}18-25 \text { yrs } \\
26-35 \text { yrs } \\
36-45 \text { yrs } \\
\text { Above } 45 \text { yrs } \\
\text { Total }\end{array}$} & 70 & 70.0 & 70.0 & 70.0 \\
\hline & 12 & 12.0 & 12.0 & 82.0 \\
\hline & 11 & 11.0 & 11.0 & 93.0 \\
\hline & 7 & 7.0 & 7.0 & 100.0 \\
\hline & 100 & 100.0 & 100.0 & \\
\hline EDUCATION QUALIFICATION & Frequency & Percent & Valid Percent & Cumulative Percent \\
\hline \multirow{5}{*}{$\begin{array}{c}\text { Intermediate } \\
\text { Degree } \\
\text { PG } \\
\text { Others } \\
\text { Total }\end{array}$} & 2 & 2.0 & 2.0 & 2.0 \\
\hline & 21 & 21.0 & 21.0 & 23.0 \\
\hline & 68 & 68.0 & 68.0 & 91.0 \\
\hline & 9 & 9.0 & 9.0 & 100.0 \\
\hline & 100 & 100.0 & 100.0 & \\
\hline OCUPATION & Frequency & Percent & Valid Percent & Cumulative Percent \\
\hline \multirow{5}{*}{$\begin{array}{c}\text { Associate } \\
\text { Associate Executives } \\
\text { Manager } \\
\text { Others } \\
\text { Total }\end{array}$} & 49 & 49.0 & 49.0 & 49.0 \\
\hline & 27 & 27.0 & 27.0 & 76.0 \\
\hline & 20 & 20.0 & 20.0 & 96.0 \\
\hline & 4 & 4.0 & 4.0 & 100.0 \\
\hline & 100 & 100.0 & 100.0 & \\
\hline INCOME LEVEL & Frequency & Percent & Valid Percent & Cumulative Percent \\
\hline \multirow{6}{*}{$\begin{array}{c}\text { Less than } 5000 \\
5001-10000 \\
10001-20000 \\
20001-30000 \\
30001-45000 \\
\text { Total }\end{array}$} & 26 & 26.0 & 26.0 & 26.0 \\
\hline & 20 & 20.0 & 20.0 & 46.0 \\
\hline & 29 & 29.0 & 29.0 & 75.0 \\
\hline & 16 & 16.0 & 16.0 & 91.0 \\
\hline & 9 & 9.0 & 9.0 & 100.0 \\
\hline & 100 & 100.0 & 100.0 & \\
\hline
\end{tabular}

Source: Primary Data 
The above table presents the frequency distribution of participants the gender $74 \%$ were male and 26\% were female, the Age group 18-25 respondents were 70\% participants, education qualification of respondents were P.G level $68 \%$ participants and the income levels of participants were $29 \%$.

Table 2 Descriptive Statistics

\begin{tabular}{|c|c|c|c|c|c|c|c|}
\hline & $\mathrm{N}$ & Minimum & Maximum & Mean & Std. Deviation & \multicolumn{2}{c|}{ Skewness } \\
\cline { 2 - 8 } & Statistic & Statistic & Statistic & Statistic & Statistic & Statistic & Std. Error \\
\hline GENDER & 100 & 1 & 2 & 1.26 & .441 & 1.111 & .241 \\
\hline AGE & 100 & 1 & 4 & 1.55 & .947 & 1.529 & .241 \\
\hline $\begin{array}{c}\text { EDUCATION } \\
\text { QUALIFICATION }\end{array}$ & 100 & 2 & 5 & 3.84 & .598 & -.509 & .241 \\
\hline OCUPATION & 100 & 1 & 4 & 1.79 & .902 & .768 & .241 \\
\hline INCOME LEVEL & 100 & 1 & 5 & 2.62 & 1.277 & .246 & .241 \\
\hline Valid N (listwise) & 100 & & & & & & \\
\hline
\end{tabular}

Source: Primary Data

Table 2 presents the basic descriptive statistics of participants on the variables and intercorrelations among them. The table shows that the combined mean age of 1.26 with a standard deviation of $0.441 .75 \%$ of the participants were male and $26 \%$ were females. The mean age of participants was 1.55 , a standard deviation of 0.947 . The mean education qualification of participants was 3.84, a standard deviation of 0.598 . The mean occupation levels of participants 1.79, the standard deviation was 0.902 and mean Income level of participants was 2.62, the standard deviation was 1.227 .

Table 3 Reliability Statistics

\begin{tabular}{|c|c|}
\hline Cronbach's Alpha & N of Items \\
\hline .826 & 23 \\
\hline
\end{tabular}

The research data was analyzed by using SPSS version 23.0. The above table shows the Cronbach Alpha value of 23 variables. As per Reliability analysis the Cronbach Alpha value for good fit was 0.7 to 0.9 . The above table -3 shows combined variables can Cronbach Alfa value is 0.826 , hence the sample can accept for analysis.

\subsection{Correlation Analysis}

- Ho: there is no relationship between Emotional Intelligence and Job Satisfaction

- Ha: Ho: there is a relationship between Emotional Intelligence, and Job Satisfaction

Table 4 Correlation Analysis

\begin{tabular}{|c|c|c|c|c|}
\hline & & $\begin{array}{l}\text { Emotional } \\
\text { recognition }\end{array}$ & $\begin{array}{c}\text { Job } \\
\text { Satisfaction }\end{array}$ & $\begin{array}{l}\text { emotional } \\
\text { regulation }\end{array}$ \\
\hline \multirow{3}{*}{$\begin{array}{l}\text { Emotional } \\
\text { intelligence and } \\
\text { recognition }\end{array}$} & Pearson Correlation & 1 & $.634^{* *}$ & $.606^{* *}$ \\
\hline & Sig. (2-tailed) & & .000 & .000 \\
\hline & $\mathrm{N}$ & 100 & 100 & 100 \\
\hline \multirow[t]{3}{*}{ Job Satisfaction } & Pearson Correlation & $.634^{* *}$ & 1 & $.438^{* *}$ \\
\hline & Sig. (2-tailed) & .000 & & .000 \\
\hline & $\mathrm{N}$ & 100 & 100 & 100 \\
\hline \multirow{3}{*}{$\begin{array}{c}\text { Emotional } \\
\text { intelligence and } \\
\text { Regulation }\end{array}$} & Pearson Correlation & $.606^{* *}$ & $.438^{* *}$ & 1 \\
\hline & Sig. (2-tailed) & .000 & .000 & \\
\hline & $\mathrm{N}$ & 100 & 100 & 100 \\
\hline
\end{tabular}


The Person's correlation coefficient is a statistical tool to determine the relationship between variables; hence it was used to find the relationship among all the studied variables. The above table-4 shows the correlation value of emotional intelligence and job satisfaction correlation $r$ $=0.634$, which gives us that the two variables were moderately related to each other and the $\mathrm{p}$ value is 0.000 states that the relationship is significant.

\subsection{Regression Analysis}

The regression analysis was carried out to show the intensity between independent and dependent variables to measure the impact that an independent variable has on the dependent variable.

- Ho: There is no association between Emotional Intelligence and Job Satisfaction

- Ha: There is an association between Emotional Intelligence and Job Satisfaction

Table 5 Regression Analysis (Model Summary)

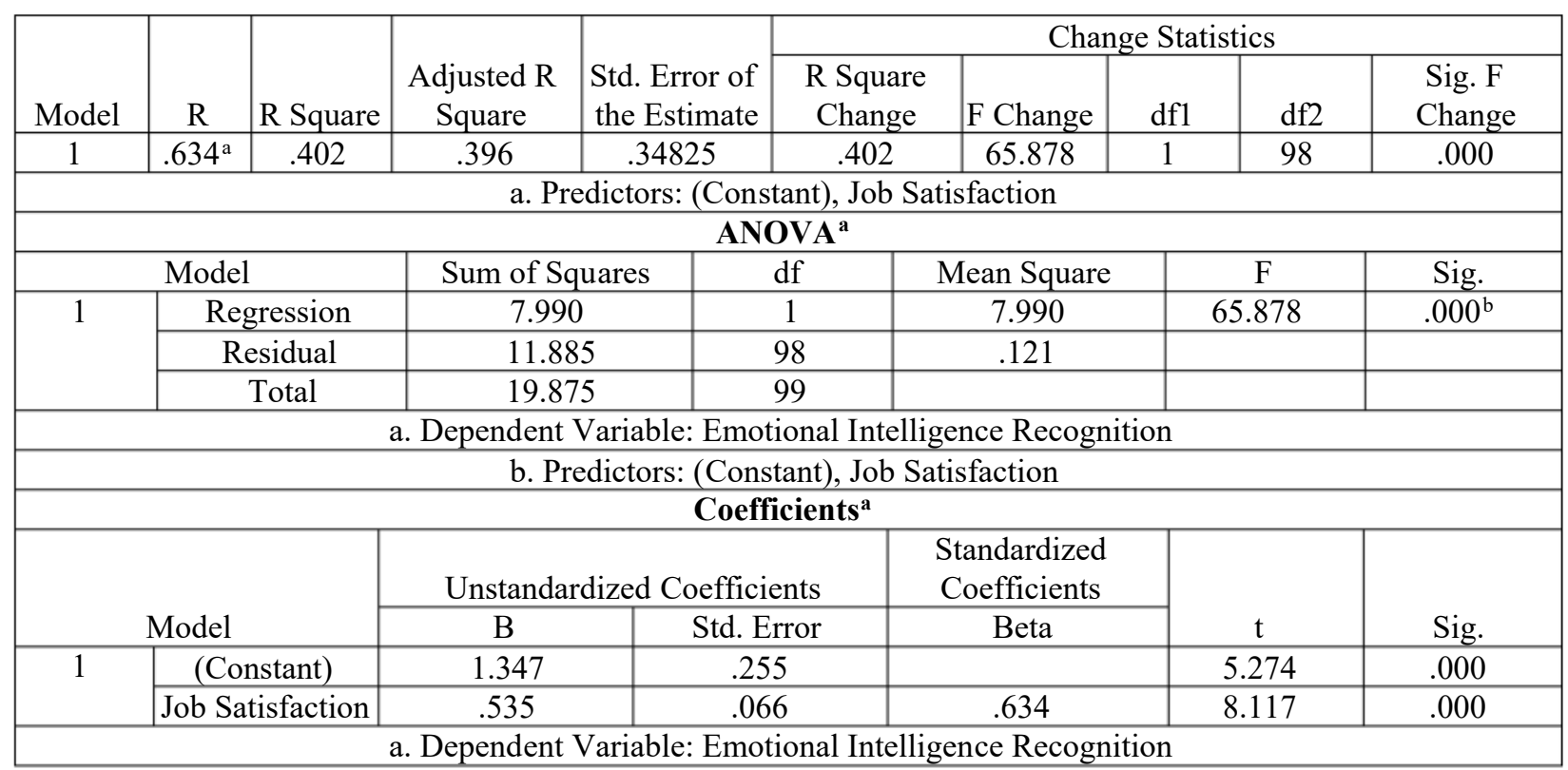

\subsubsection{Dependent Variable: Emotional Intelligence}

Form the above regression table-5 reveals that as $\mathrm{R}$ represents the correlation between the dependent variable and independent variable, it can be identified that the correlation $r$-value is 0.634 which is greater than 0.05 significant level. The coefficient of determination is 0.634 about $63.4 \%$ of the variation in job satisfaction. Form the above regression equation can be made as

$$
\text { Job Satisfaction }=1.347+(0.535) * \text { Emotional intelligence }
$$

The above coefficients state that the job performance in increases by 0.535 of increase in emotional intelligence. And $\mathrm{t}$ value 5.274 identified the relationship between emotional intelligence recognition and job satisfaction. The significant value is 0.000 is less than 0.05 . Hence it concludes that there is a significant difference between emotional intelligence and job satisfaction.

From the ANOVA table states that $\mathrm{F}$ value is 5.274, the significant value is 0.000 is less the 0.05 . Hence we can reject the null hypothesis. It is evident that the model is a good fit for the data and will apply to the sample population. 
- Ho: There is no significant difference between Demographic Characteristics and Job Satisfaction

- Ha: There is a significant difference between Demographic Characteristics and Job Satisfaction

Table 6 Regression Analysis Model Summary

\begin{tabular}{|c|c|c|c|c|c|c|c|c|c|c|c|}
\hline \multirow[b]{2}{*}{ Model } & \multirow[b]{2}{*}{$\mathrm{R}$} & \multirow[b]{2}{*}{ R Square } & \multirow[b]{2}{*}{$\begin{array}{l}\text { Adjusted R } \\
\text { Square }\end{array}$} & \multirow{2}{*}{\multicolumn{2}{|c|}{$\begin{array}{l}\text { Std. Error of } \\
\text { the Estimate }\end{array}$}} & \multicolumn{6}{|c|}{ Change Statistics } \\
\hline & & & & & & \multicolumn{2}{|c|}{$\begin{array}{c}\text { R Square } \\
\text { Change }\end{array}$} & F Change & df1 & df 2 & $\begin{array}{c}\text { Sig. F } \\
\text { Change }\end{array}$ \\
\hline 1 & $.438^{\mathrm{a}}$ & .192 & .184 & .501 & & & & 23.272 & 1 & 98 & .000 \\
\hline \multicolumn{12}{|c|}{ a. Predictors: (Constant), Job Satisfaction } \\
\hline \multicolumn{12}{|c|}{ ANOVA $^{a}$} \\
\hline \multicolumn{3}{|c|}{ Model } & \multirow{2}{*}{\multicolumn{2}{|c|}{ Sum of Squares }} & \multicolumn{2}{|c|}{$\mathrm{df}$} & & ean Square & \multicolumn{2}{|c|}{$\mathrm{F}$} & Sig. \\
\hline \multirow[t]{3}{*}{1} & \multirow{2}{*}{\multicolumn{2}{|c|}{$\frac{\text { Regression }}{\text { Recidual }}$}} & & & \multicolumn{2}{|c|}{1} & & 5.854 & \multicolumn{2}{|c|}{23.272} & $.000^{\mathrm{b}}$ \\
\hline & & & \multicolumn{2}{|c|}{24.651} & & & & .252 & & & \\
\hline & \multicolumn{2}{|c|}{ Total } & 30.50 & & \multicolumn{2}{|c|}{99} & & & & & \\
\hline \multicolumn{12}{|c|}{ a. Dependent Variable: Emotional Intelligence Regulation } \\
\hline \multirow{2}{*}{\multicolumn{12}{|c|}{$\begin{array}{c}\text { b. Predictors: (Constant), Job Satisfaction } \\
\text { Coefficients } \mathbf{s}^{\mathbf{a}}\end{array}$}} \\
\hline & & & & & \multicolumn{3}{|c|}{ Coefficients $^{\mathbf{a}}$} & & & & \\
\hline \multirow{2}{*}{\multicolumn{3}{|c|}{ Model }} & \multicolumn{4}{|c|}{ Unstandardized Coefficients } & \multicolumn{2}{|c|}{$\begin{array}{l}\text { Standardized } \\
\text { Coefficients }\end{array}$} & \multirow{2}{*}{\multicolumn{2}{|c|}{$\mathrm{t}$}} & \multirow[b]{2}{*}{ Sig. } \\
\hline & & & B & & Std. Er & & & Beta & & & \\
\hline \multirow[t]{2}{*}{1} & \multicolumn{2}{|c|}{ (Constant) } & 2.178 & \multicolumn{3}{|c|}{.368} & & & \multicolumn{2}{|c|}{5.923} & .000 \\
\hline & \multicolumn{2}{|c|}{ ES } & .458 & \multicolumn{3}{|c|}{.095} & & .438 & & & .000 \\
\hline
\end{tabular}

Form the above regression table- 6 reveals that as $\mathrm{R}$ represents the correlation between the dependent variable and independent variable, it can be identified that the correlation $r$ value is 0.438 which is less than 0.05 significant levels. The coefficient of determination is 0.438 about $43.8 \%$ of the variation in the job satisfaction. Form the above regression equation can be made as

Job Performance $=2.178+(0.458) *$ Emotional intelligence Recognition

The above coefficients states that the job performance in increases by 0.458 of increase in emotional intelligence. And t value 5.923 identified the relationship between emotional intelligence recognition and job satisfaction. The significant value is 0.000 is less than 0.05 . Hence it concludes that there is a significant difference between emotional intelligence regulation and job satisfaction.

From the ANOVA table states that $\mathrm{F}$ value is 23.272 , the significant value is 0.000 is less the 0.05 . Hence we can reject the null hypothesis. It is evident that the model is a good fit for the data and will apply to the sample population.

- Ho: There is no significant difference between Demographic and Job Satisfaction

- Ha: There is a significant difference between Demographic and Job Satisfaction

Table 7 ANOVA

\begin{tabular}{|c|c|c|c|c|c|c|}
\hline \multicolumn{2}{|c|}{} & Sum of Squares & df & Mean Square & F & Sig. \\
\hline \multirow{4}{*}{ Age } & Between Groups & 26.661 & 19 & 1.403 & 1.808 & .036 \\
\cline { 2 - 7 } & Within Groups & 62.089 & 80 & .776 & & \\
\cline { 2 - 7 } & Total & 88.750 & 99 & & & \\
\hline \multirow{2}{*}{\begin{tabular}{c} 
Education $\begin{array}{c}\text { Qualificati } \\
\text { on }\end{array}$ \\
\cline { 2 - 7 }
\end{tabular}} & Between Groups & 9.314 & 19 & .490 & 1.501 & .108 \\
\cline { 2 - 8 } & Within Groups & 26.126 & 80 & .327 & & \\
\hline Ocupation & Total & 35.440 & 99 & & & \\
\hline
\end{tabular}


Impact of Emotional Intelligence on Job Satisfaction at Tata Consultancy Services, Chennai, Tamilnadu State A Case Study

\begin{tabular}{|c|c|c|c|c|c|c|}
\hline \multirow{4}{*}{$\begin{array}{c}\text { Income } \\
\text { Level }\end{array}$} & Within Groups & 55.325 & 80 & .692 & & \\
\cline { 2 - 6 } & Total & 80.590 & 99 & & & \\
\cline { 2 - 7 } & Between Groups & 56.317 & 19 & 2.964 & 2.253 & .006 \\
\cline { 2 - 7 } & Within Groups & 105.243 & 80 & 1.316 & & \\
\hline \multirow{3}{*}{ Gender } & Total & 161.560 & 99 & & & .001 \\
\cline { 2 - 7 } & Between Groups & 7.759 & 19 & .408 & & \\
\cline { 2 - 7 } & Within Groups & 11.481 & 80 & .144 & & \\
\cline { 2 - 7 } & Total & 19.240 & 99 & & & \\
\hline
\end{tabular}

The ANOVA analysis in the table shows that the result of age and job satisfaction $F$ value is 1.808 , the significance value is 0.036 . Education qualification and Job satisfaction $F$ value is 1.501, significance value is 0.108 . Occupation and Job satisfaction $F$ value is 1.923 , significance value is 0.023 , Income level and Job satisfaction F value is 2.253 , significance value is 0.006 . Gender and Job satisfaction $F$ value is 2.846 , significance value is 0.001 . Hence it concludes that education qualification and job satisfaction there is no significance the value at 0.108 is greater than the 0.05 .

- Ho: There is no significant difference between Demographic and emotional recognition

- Ha: There is a significant difference between Demographic and emotional recognition

Table 8 ANOVA

\begin{tabular}{|c|c|c|c|c|c|c|}
\hline & & Sum of Squares & df & Mean Square & $\mathbf{F}$ & Sig. \\
\hline \multirow[t]{3}{*}{ AGE } & Between Groups & 27.977 & 8 & 3.497 & 5.237 & .000 \\
\hline & Within Groups & 60.773 & 91 & .668 & & \\
\hline & Total & 88.750 & 99 & & & \\
\hline \multirow{3}{*}{$\begin{array}{c}\text { EDUCATION } \\
\text { QUALIFICATIO } \\
\mathrm{N}\end{array}$} & Between Groups & 5.442 & 8 & .680 & 2.064 & .048 \\
\hline & Within Groups & 29.998 & 91 & .330 & & \\
\hline & Total & 35.440 & 99 & & & \\
\hline \multirow[t]{3}{*}{ OCUPATION } & Between Groups & 16.807 & 8 & 2.101 & 2.997 & .005 \\
\hline & Within Groups & 63.783 & 91 & .701 & & \\
\hline & Total & 80.590 & 99 & & & \\
\hline \multirow[t]{3}{*}{ INCOME LEVEL } & Between Groups & 20.939 & 8 & 2.617 & 1.694 & .110 \\
\hline & Within Groups & 140.621 & 91 & 1.545 & & \\
\hline & Total & 161.560 & 99 & & & \\
\hline \multirow[t]{3}{*}{ GENDER } & Between Groups & 5.359 & 8 & .670 & 4.392 & .000 \\
\hline & Within Groups & 13.881 & 91 & .153 & & \\
\hline & Total & 19.240 & 99 & & & \\
\hline
\end{tabular}

The ANOVA analysis in the table shows that the result of age and emotional recognition $\mathrm{F}$ value is 5.237 , significance value is 0.000 . Education qualification and emotional recognition $\mathrm{F}$ value is 2.604, significance value is 0.048 . Occupation and emotional recognition $F$ value is 2.997, significance value is 0.005 , Income level and emotional recognition $F$ value is 1.694 , significance value is 0.110 . Gender and Job satisfaction $F$ value is 4.392 , significance value is 0.000 . Hence it concludes that income and emotional recognition there is no significance the value at 0.110 is greater than the 0.05 .

- Ho: There is no significant difference between Demographic and emotional regulation

- Ha: There is a significant difference between Demographic and emotional regulation 
Table 9 ANOVA

\begin{tabular}{|c|c|c|c|c|c|c|}
\hline & & Sum of Squares & df & Mean Square & $\mathbf{F}$ & Sig. \\
\hline \multirow[t]{3}{*}{ Age } & Between Groups & 48.694 & 14 & 3.478 & 7.381 & .000 \\
\hline & Within Groups & 40.056 & 85 & .471 & & \\
\hline & Total & 88.750 & 99 & & & \\
\hline \multirow[t]{3}{*}{ Education Qualification } & Between Groups & 12.434 & 14 & .888 & 3.282 & .000 \\
\hline & Within Groups & 23.006 & 85 & .271 & & \\
\hline & Total & 35.440 & 99 & & & \\
\hline \multirow[t]{3}{*}{ Ocupation } & Between Groups & 37.473 & 14 & 2.677 & 5.277 & .000 \\
\hline & Within Groups & 43.117 & 85 & .507 & & \\
\hline & Total & 80.590 & 99 & & & \\
\hline \multirow[t]{3}{*}{ Income Level } & Between Groups & 54.991 & 14 & 3.928 & 3.133 & .001 \\
\hline & Within Groups & 106.569 & 85 & 1.254 & & \\
\hline & Total & 161.560 & 99 & & & \\
\hline \multirow[t]{3}{*}{ Gender } & Between Groups & 8.473 & 14 & .605 & 4.778 & .000 \\
\hline & Within Groups & 10.767 & 85 & .127 & & \\
\hline & Total & 19.240 & 99 & & & \\
\hline
\end{tabular}

The ANOVA analysis in the table shows that the result of age and emotional regulation $\mathrm{F}$ value is 7.381 , the significance value is 0.000 . Education qualification and emotional regulation $F$ value is 3.282 , significance value is 0.000 . Occupation and emotional regulation $F$ value is 5.277 , significance value is 0.000 , Income level and emotional regulation $F$ value is 3.133 , significance value is 0.001 . Gender and Job satisfaction $F$ value is 4.778 , significance value is 0.000 . Hence it concludes that age, educational qualification, occupation, income level gender and emotional regulation there is a significance the value at 0.00 is greater than the 0.05 .

\section{FINDINGS}

The participants of the gender $74 \%$ were male and $26 \%$ were female, the Age group 18-25 respondents were $70 \%$ participants, education qualification of respondents were P.G level $68 \%$ participants and the income levels of participants were $29 \%$.

A correlation value of emotional intelligence and job satisfaction correlation $r=0.634$, which gives us that the two variables were moderately related to each other and the p-value is 0.000 states that the relationship is significant. Emotional intelligence and job satisfaction correlation $\mathrm{r}=0.438$, which gives us that the two variables were less moderately related to each other and the $\mathrm{p}$-value is 000 states that the relationship is not significant.

The regression analysis shows that there is a significant difference between emotional intelligence and job satisfaction.

The analysis variance shows that there is a significant difference between emotional intelligence and job satisfaction.

\section{CONCLUSION}

The impact of the individual activities over some time is regarded as performance. Organizational productivity and success of the organization depend on directly related to the management of employee performance. Emotional intelligence is now being identified as a good predictor of employees' work performance. The organization should require individual interpersonal interactions with the goals of organization. Emotional intelligence is playing a vital role in the workplace. Employees can handle their emotions accurately and behaviors in the workplace to make better decisions. In the workplace, employees depend on working with a group of people with different ideas, suggestions and opinions. The high Emotional intelligence individual and the group can better perceive emotions. The organization should 
Impact of Emotional Intelligence on Job Satisfaction at Tata Consultancy Services, Chennai, Tamilnadu State A Case Study

consider EI as a part of recruitment, selection, training and development as a part of individual job performance, which leads to the growth of the organization.

\section{REFERENCES}

[1] Ealias. A. and J. George, —Emotional intelligence and job satisfaction: A Correlational Study,॥ The International Journal's Research Journal of Commerce and Behavioral Science, 2012

[2] Goleman D, Working with Emotional Intelligence, New York: Bantam Books, Hay/McBer, 2000 .

[3] Hayward, B. A. 2005. Relationship between employee performance, leadership and emotional intelligence in a South African Parastatal organization. Master.Thesis.Department of Management.

[4] H. S. Pande, -Evaluating characteristics and emotional intelligence among workers in organizations in the state of Rajasthan,\| International Research Journal, vol. 1, issue 10, 2010.

[5] Jorfi, H., Fauzy Bin Yacco, H. and Md. Shah, I. (2012). Role of gender in emotional intelligence: Relationship among emotional intelligence, communication effectiveness and job satisfaction. Internat. J. Mgmt., 29(4) : 590-597.

[6] Kurien, J.S. (2013). The role of emotional intelligence in customer service quality: A review of the service sector. Asia Pacific J. Mgmt. \& Entrepreneurship Res., 2(2) : 74-91.

[7] Khokhar, C.P. and Kush, T. 2009. Emotional intelligence and work performance among executives. Europe's Journal of Psychology.

[8] Kernbach, S. and Schutte, N.S. (2005). The impact of service provider emotional intelligence on customer satisfaction. J. Services Mktg., 19(7) : 438-444.

[9] Khouly, E.I.S., Ghoneim, A., Ghadami, M., \& Ibrahim, M. (2011). Impact of emotional intelligence and gender on job satisfaction among Egyptian government sector employees. Current Research Journal of Social Sciences, 3(1), 22-27. Retrieved from http://papers.ssrn.com/sol3/papers.cfm?abstract_i d $=1951846$

[10] Nel, H. and De Villiers, W.S. 2004. The relationship between emotional intelligence and job performance in a call center environment. SA Journal of Industrial Psychology.30 (3):75-81.

[11] Radhakrishnan, A. and UdayaSuriyan, G. (2010). Emotional intelligence and its relationship with leadership practices. Internat. J. Bus. \& Mgmt., 5(2) : 65.

[12] Syed, S.S.S., Rohany, N., Mohammad, A.S.M.A., \& Muhammad, B.M. (2012). The role of emotional intelligence and job satisfaction among school teachers. The Social Science, 7(1), 125-129. DOI: $10.3923 /$ science.2012.125.129

[13] Tabatabaei, S. O., \&Farazmehr, Z. (2015). The relationship between Emotional Intelligence and Iranian Language Institute Teacher' Job Satisfaction. Theory and Practice in Language Studies, 5 (1), 184195. doi:10.17507/tpls.0501.25

[14] Yao, Y.H. Wang, R.T. And Karen Y. W. 2009. The influence of emotional intelligence on job performance: Moderating effects of leadership. International conference on management science \&engineering:14-16. 